\title{
Internationalization of Product-Service Systems: Global, Regional or National Strategy?
}

\author{
Glenn Parry \\ Associate Professor, Bristol Business School, University of the West of England, UK. Address: BS16 1QY Bristol, United \\ Kingdom. E-mail: glenn.parry@uwe.ac.uk \\ Oscar Bustinza \\ Associate Professor, Universidad de Granada, Spain. Address: 18071 Granada, Spain. E-mail: oscarfb@ugr.es
}

\section{Ferran Vendrell-Herrero}

Lecturer, University of Birmingham, UK. Address: B15 2TT Birmingham, United Kingdom.

E-mail: f.vendrell-herrero@bham.ac.uk

\section{Nicholas O'Regan}

Professor, Bristol Business School. E-mail: Nicholas.O’Regan@uwe.ac.uk

\begin{abstract}
$\mathrm{H}$

ighly dynamic market environment, knowledge creation and technology advancement demands that producers/providers need to be more efficient and effective in meeting existing and future consumer needs and expectations. In this regard, companies strive, as deeply as possible, to diversify a range of proposed products as well as strategies for their commercialisation.

Using the case of music industry, this paper explores the validity of national, regional or global strategies in the provision of a product service system. The authors surveyed over 70,000 respondents from fifteen geographically spread countries which account for more than $85 \%$ of the

global revenues of the industry. The analysis of the survey results identified a homogeneous group of so-called Out of Touch consumers characterized by their attitude: they are interested in and have money for, but no-longer purchase music. The authors attempt to ascertain if and how reengaging the group in music purchase would achieve a significant sales increase. The analysis explores how potential consumers might respond to, or are able to be influenced by, value offerings in fifteen different countries.

Findings suggest that firms may employ global strategies for supply of products and services, but regional strategies are required to define the appropriate bundles to re-engage Out of Touch consumers.
\end{abstract}

Keywords: globalisation; regionalisation; internationalization; product services bundles; relationships value propositions; music industry

DOI: 10.17323/1995-459x.2016.1.16.29
Citation: Parry G., Bustinza O., Vendrell-Herrero F., O’Regan N. (2016) Internationalization of ProductService Systems: Global, Regional or National Strategy? Foresight and STI Governance, vol. 10, no 1, pp. 16-29. DOI: 10.17323/1995-459x.2016.1.16.29 
$\mathrm{T}$ he ever-changing and highly dynamic market environment demands that producers/providers be more efficient and effective in meeting existing and future consumer needs and expectations [O'Regan, 2012]. In addition, the creation of new knowledge and technologies has re-enforced differentiation for some firms [Neu, Brown, 2005]. To address such challenges, firms need to explore ways to achieve, retain, or regain competitive advantage. The exploitation of business opportunities often requires new business models that create value for both the company and consumer [Breunig et al., 2013]. Consumer input to product and service development has been likened to an 'arms-length research team' [Berthon et al., 2007]. Consumers are now more engaged as value co-creators with provider firms and so value is created together with engaged consumers [Chandra, Coviello, 2010]. To ensure competitive advantage underpinned by differentiation, products should ideally be co-created with partners and emphasis should be placed on the value perceived by the consumer [Vargo, Lusch, 2008]. Lusch et al. include the wider stakeholder community in the co-creation of value with the consumer [Lusch et al., 2010]. It is clear that consumers are becoming more dynamic and less willing to passively accept what is available in the marketplace [Kucuk, Krishnamurthy, 2007]. Consumers whose demands are unmet by firms may seek to fill the niche in the marketplace through co-creating suitable alternative offerings [Berthon et al., 2007, p. 40].

Firms are becoming increasingly international and it is challenging to achieve competitive advantage through co-creation of value with globally diverse consumers [Rugman, 2009]. Despite claims that business now operates on a global basis, most companies operate on a regional or multi-domestic basis [Briscoe et al., 2009]. Previous research and existing frameworks for international business have built from a traditional strategy based on 'the vertical integration of supply and production activities to control the cost, disciplined research to create superior products; and a dominant market position to provide economies of scale' [Wise, Baumgartner, 1999, p. 134]. This 'upstream' approach is supplier-centric and does not address the importance of downstream consumer activities. Consumer activity can be used to expand the value chain by 'shifting to customer allegiance': and changes the role of the consumer who, as a result of internet technology, can become actively engaged in shaping and assessing a firm's products [Rugman, Verbeke, 2003]. This paper explores the validity of global, regional, ${ }^{1}$ and country specific strategies with regards to the downstream consumer facing activity of a Global Multi National Enterprise (MNE). Global MNEs provide the corporate strategy and organizational structure for their regional subsidiaries, which tend to be largely homogeneous at the global level [Djelic, Quack, 2003]. With the changing role of the consumer, it is relevant to analyze whether such homogeneity meets the needs and requirements of consumers. We explore this using a dataset created by an international MNE and capturing consumer preferences and purchasing attitudes from 15 countries from the broad triad regions of Japan, Western Europe, and North America.

This paper examines propositions contingent with strategy at the geographical level of analysis: global, region, or country specific. Our focus is placed upon a single consumer group whose attitude towards the purchase of goods may be described as Out of Touch. This important group embodies potential consumers who have the means and resources to make purchases but who have not done so recently. They represent a significant potential market, ranging from $8 \%$ in Sweden, to $10 \%$ in the USA, $25 \%$ in India, and up to $33 \%$ in the Netherlands. Re-engaging these consumers would significantly increase revenues for the industry. The analysis explores how potential consumers might respond to, or are able to be influenced by, value offerings in 15 different countries. This sheds light on whether the strategy for re-engagement of consumers is a matter of global, regional, or national strategy implementation.

\section{Theoretical framework}

\section{Choosing scale of internationalization strategies}

From a firm perspective, the Uppsala School [Johanson, Vahlne, 1977] presents international expansion as a sequential process. Growth extends from the country to regions, with increasing geographical distance from the home base presented as a proxy for increasing risk [Kogut, Singh, 1988]. More recently, the Uppsala School has added a networking perspective, which purports that firms, as well as their suppliers and consumers, are in a network that is beneficial to each in terms of knowledge exchange and commitment [Johanson, Vahlne, 1997].

The challenge of setting strategy at global or regional level results from the internationalization of a national firm. Internationalization provides the opportunity for firms to gain revenue in many markets [Kafouros et al., 2008], which in turn provides an opportunity for growth and value capture. International market diversification is attractive for MNEs as it provides a means to gain more stable revenues than would be received by a similar sized domestic firm [Rugman, 2009]. It is argued that growth from internationalization involves the transfer of resources across national borders, where country selection and entry mode choice are the key strategic decisions [Madhok, 1997].

${ }^{1}$ Hereinafter, a region referred as a group of neighboring countries belonging to a certain geographical region $(E d$.). 
Academics continue to explore whether an internationalized business is necessarily a truly global, multinational business, or if the construct more accurately relates to regional and multi-local business activities [Schmid, Kotulla, 2011]. Yip [Yip, 2003] proposes that a firm must set a clear global strategy before determining their regional and national strategies. This assumes that a hierarchy in decision making exists, which could arguably not give sufficient recognition to the consumer as a resource/asset for the firm as part of the strategic value creation process [DeSarbo et al., 2001; Vargo, Lusch, 2004]. Global strategy assumes that global strategic intent can dictate regional and national strategic actions, a sequence Rugman and Verbeke [Rugman, Verbeke, 2003] suggest is unlikely to occur. Rugman's work suggests that MNEs are, in practice, operating regionalized strategies [Rugman, Oh, 2008]. Others propose a strategic model that includes national, regional, and global levels, each distinct but inter-related [Ghemawat, 2005]. In all cases, firms are challenged with finding an optimum strategy between the adoption of a global standard of leading practice and adaptation to national or regional difference, thus balancing globalization, regionalization, and multi-national activities [Ghoshal, Westney, 1993; Husted, Allen, 2006]. In all cases, data analysis at the country-level is required to produce evidence to support regional or global claims [Dunning et al., 2007]. It is proposed that the transfer of standard practice requires that homogeneous market conditions exist across national boundaries, including regulations, custom, tradition, and consumer characteristics [Katsikeas et al., 2006]. Such interaction is assumed to bring a convergence across cultural, political, and economic life [Giddens, 2011]. The transfer of global resources and practice leads to a phenomena where there is an attempt to standardize and subjugate the local [Ritzer, 2003], creating a dialectic between global and national [Hargrave et al., 2009].

Whilst goods, services, and people have significant freedom of movement across the world, a transition towards homogeneity between multiple nations is contested [Robertson, Khondker, 1998]. Management approaches and technologies may be globally convergent, but the context of MNE operations is derived from national cultures [De Jong et al., 2011]. Any global initiatives necessarily require regional teams that both understand their regional operating context to implement them effectively [Ghemawat, 2005] and the local consumer market, such that the value proposition can be clearly designed and communicated [DeSarbo et al., 2001] since contextual differences between markets may lead to significantly different outcomes [Evans et al., 2008]. This has been described as globalization [Ritzer, 2003], where global and national interpenetrate, creating heterogeneity rather than homogeneity [Pieterse, 2009].

\section{Music industry context}

Most of the content of the music industry has international appeal [IFPI, 2011] and historically consumers have been known to share a range of similar preferences all over the world. However, strategies to approach or interact with consumers could be substantially different at the national level. For example, Bakker [Bakker, 2006] — in an exhaustive review of the evolution of the multinational business in the music industry during the second half of the $20^{\text {th }}$ century - argues that MNEs extracted the maximum profits by transferring their property rights catalogue to national subsidiaries or intermediaries, who understand better the nature of national markets. The existence of local subsidiaries with property rights provides evidence that the MNEs were employing local consumer strategies during the later 20th century, before revenues started to decrease due to the digitization of music. This work questions whether technological change, driven by internet adoption, may have modified the optimal strategy.

Whilst the concept of globalization has no agreed single definition, in the music industry it is viewed as a homogenizing force affecting all aspects of the industry [Ho, 2003]. Academic discussion on the nature of music content that globalization is linked to necessarily includes a discussion about the globalization of the music industry [Stokes, 2004]. Globalization has been linked to the creation of music as a commoditized disposable item; part of a move towards a homogenized global culture [Feld, 2001]. However, despite the global success of some artists, studies have shown that consumers retain a bias towards domestic music [Ferreira, Waldfogel, 2010].

The internet has made music available to a global audience, with online sites disseminating and providing access to mainstream as well as niche music [Brynjolfsson et al., 2006]. The internet provides firms with global reach and coherence for a business operating along the lines of a global strategy [Yip, 2003]. Offering music via the internet makes it easier for firms to provide a globally standard offer. Standard value propositions that deliver music content to customers via web platforms can be created that can serve the global customer base. A standard global consumer facing offer means that the unseen 'backoffice' functions of the business can be rationalized and where regional differences are required, these points of difference may be more easily coordinated. Global headquarters manage the transfer of innovations [Dellestrand, 2011] and provide support to a network of national and regional operational and marketing functions. Restructuring value chains is seldom limited to geographic boundaries, instead it often transgresses national borders [Bustinza et al., 2013a]. Supply chain data on different artist's sales on particular platforms from across multiple countries is often quoted, such as the global number of YouTube views, demonstrating that some global standardization is already happening.

There are financial incentives for standardization as product standardization leads to efficient financial performance [Ballard et al., 2009]. International revenue growth is important as there is a clear 
correlation between digitalization (i.e. broadband, file sharing services) and revenue decline in the music industry, principally due to a decrease in physical sales [IFPI, 2011]. Many intermediary operations and associated firms have been removed from the music supply chain as digital music formats are traded online, replacing traditional physical sales with online service products [Graham et al., 2004]. Music firms who previously made their money from physical format sales, such as $\mathrm{CD}$ and vinyl, are now seeking additional value and revenue through online digital music services in a process that has been described as the 'servitization of the music industry' [Parry et al., 2012; Vandemerwe, Rada, 1988]. Although a body of research has analyzed upstream supply chain management, far less is to be found with a focus on the downstream value chain management of sales channels, where consumers are engaged and service-based advantages are available [Singer, Donoso, 2008; Wise, Baumgartner, 1999]. Downstream, the global music market is constructed to target the most profitable categories of recorded music [Negus, 1999]. Music industry MNEs retain national marketing and operation functions in all their major country markets, such that the consumer end of the value chain- the point of exchange and use of the product [O'Cass, Ngo, 2011] - may be less amenable to integration into global models [Bustinza et al., 2013b]. However, superior performance may be achieved by creating unique value offerings from a global standard portfolio tailored to a local/regional context [Ngo, O'Cass, 2009].

As music moves towards more service-oriented models of delivery, music distributors are exploring suitable international alliances with exclusive platform producers. The goal is to create value propositions that allow distributors to gain market position and revenues while regaining a degree of control in the value chain [Swatman et al., 2006]. Internationalization of the music industry exposes the content to a larger audience as well as helps return investments made in developing and marketing music technologies [Hitt et al., 1994]. Empirical evidence show the performance of manufacturing firms begins to decrease after a certain level of international expansion because managing complex international operations proves costly. However, multinational service firms are likely to perform differently, with studies suggesting that high levels of international diversity tend to increase service firm performance [Contractor et al., 2007]. This may imply that a multinational - if not truly global [Rugman, Oh, 2008] — or regional strategy may work for service firms.

\section{Context and hypotheses}

Music industry MNEs have extensive global experience and yet retain national subsidiaries in their key markets [Bakker, 2006; Johanson, Vahlne, 1977]. They have also conducted extensive international research to gain an understanding of the consumers in these markets [Chandra, Coviello, 2010]. Empirical studies based on UK consumer data have led to the creation of groups of potential music consumers clustered by their attitudes towards music [Parry et al., 2012]. This study was conducted among a select sample of people who have disposable income but do not currently engage in value exchanges. This group is described as Out of Touch. Analysis of this group in the UK indicated that they had a positive attitude towards music purchase and so potentially could be engaged in other markets through provision of suitable value offerings. The main objective for firms is to create and maintain value [Sirmon et al., 2007], and the Out of Touch group is a potentially interesting unit for this global study as they represent around $20 \%$ of potential global consumers; hence, offering the greatest potential for future value capture.

Finding the appropriate strategy is proving to be a challenge for MNEs. A global strategy means using a common approach to meet the needs of consumers who may have disparate or fragmented requirements [Brynjolfsson et al., 2006]. In contrast, it has been stated that to be successful, firms must utilize their knowledge gained in other markets and adapt that knowledge to national contexts, suggesting either regional or national strategies [Boisot, 1998]. Irrespective of the level of sales, market orientation becomes highly significant as it demonstrates the extent of a firm's engagement in marketing activities and consumer intelligence [Morgan et al., 2009]. Empirical research suggests that market orientation is a generic determinant of firm performance [Ellis, 2006; Kirca et al., 2005]. Whilst there can be no single approach to product strategy in international markets [Hultman et al., 2009], the key market resource of firms is an understanding of the different preferences of consumers, or potential consumers in a market [Vargo, Lusch, 2004]. Knowledge of the national market allows for the development of specific consumer segments [Srivastava et al., 2001]. Music MNEs are also able to have operations and management functions geo-located in all their major market countries. Firms may target a broad range of consumers or a focused audience with a specific need or preference [Boone et al., 2002].

Value propositions are used by firms to engage consumers and encourage them to purchase products. Relationship value [Payne, Holt, 2001] denotes if it is possible to engage with and influence consumers, to increase the likelihood of purchase [Afuah, 2002; Bustinza et al., 2013a]. Value captured is the worth, usually monetary, which firms secure through value exchange with consumers who purchase their offering [Lepak et al., 2007]. This study builds upon previous work that empirically examines consumer attitudes to value offerings [Parry et al., 2012] and potential behaviour at the point of value in use [O'Cass, Ngo, 2011].

Parry et al. [Parry et al., 2012] found that consumers' purchasing patterns are dependent on the sales format as they perceive utility differently when buying music as a product $[\mathrm{CD}$, vinyl] than as a service 
(streaming, downloads). Following this research, we expect that reengagement with the Out of Touch segment will depend on the sales formats offered by firms in a market, with some consumers retaining a preference for physical format and others engaging in digital streaming and download. From the consumer's perspective, we propose that if firms are to deliver value propositions [Ordanini, Pasini, 2008] that create value in use [Prahalad, Ramaswamy, 2000], then the attitudes of potential consumers must be matched by the marketing strategy. We must find homogeneity among attitudes to music at the national, regional, or global level. This proposal leads to the formulation of the following set of hypotheses:

Hypothesis 1. Music consumers displaying an Out of Touch attitude are positively related to purchasing music.

Hypothesis 1a: Music consumers displaying an Out of Touch attitude are positively related to purchasing music in product format.

Hypothesis 1b. Music consumers displaying an Out of Touch attitude are positively related to purchasing music in service format.

Value is determined by the consumer's response to a bundle of value deliverables in terms of product, service, and the customer relationship [O'Cass, Ngo, 2011; Vargo, Lusch, 2004] such that it is possible, using the appropriate mix of value offerings [Ngo, O'Cass, 2009], to engage with and influence consumers and increase their likelihood of making a purchase [Bustinza et al., 2013a]. According to this argument, and considering the particular characteristics of potential music consumers, it is expected that specific value strategies can positively influence consumer attitudes.

Hypothesis 2: Relationship value strategies can target the consumers with an Out of Touch attitude and increase their propensity towards purchasing music.

Having stated the hypotheses, we developed a model of relationships and this is shown in Figure 1.

\section{Methodology}

To examine these hypotheses it is necessary to carry out an empirical investigation. The study population comprises resident music consumers from 15 countries that account for more than $85 \%$ of the global revenues of the music industry and represent a broad geographical representation. The statistical software SPSS 20.0 and EQS 6.2 was used to analyze the data included in the sample. The questionnaire and responses were provided by one of the big four global music firms. The utilized questionnaire underwent iterative development for a number of years within the company's market research division. The researchers were able to influence current questions and add new ones where appropriate. The questionnaire was extensive and the researchers worked with a subset of questions that directly related to the attributes and characteristics of consumer behaviour and active strategies relevant to this study. The subset of questions, planned paper, proposed hypothesis, empirical tests and assumptions were discussed

Fig. 1. Model to measure attitudes relating to direct and mediating relationships for Out of Touch consumers

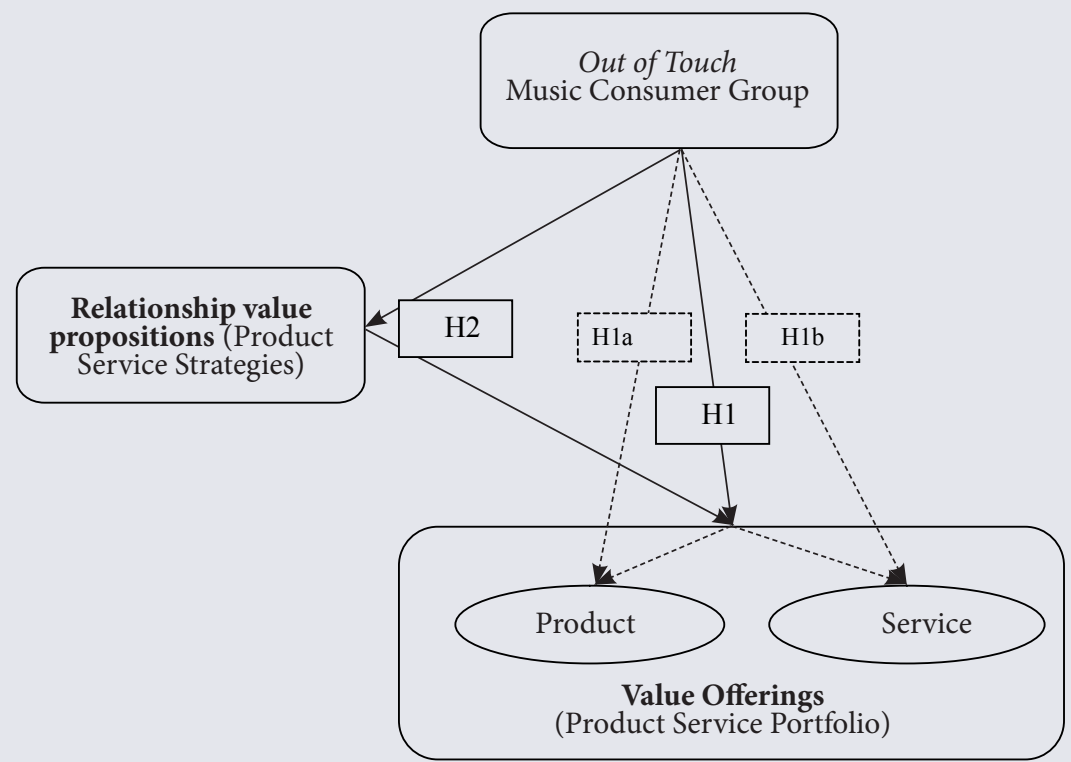

Source: compiled by the authors. 
with an industry expert group in face-to-face meetings. Findings were validated by circulating drafts of the manuscript to industry experts for coherence and accuracy.

To determine consumers' attitudes, a 5-point Likert scale (from $1=$ Total Disagreement, to $5=$ Total Agreement) was used [Parry et al., 2012]. Further analysis excluded consumers with a lack of disposable income as the main reason for those not buying music, creating the focal subgroup of Out of Touch consumers. Analysis of the scale's internal consistency for different countries present a Cronbach's alpha value over 0.700, Mean Inter-item Correlation (MIC) are below 0.500, and Composite Reliability (CR) values are over 0.700 indicating that these scales are valid measurement instruments [Hair et al., 200 1].

To identify a firm's value offerings of format, as either product or service, a scale composed of a 5-point Likert, from $1=$ Total Disagreement, to $5=$ Total Agreement, is used [Parry et al., 2012]. For analysis of the scale's internal consistency, the Cronbach's alpha value, Mean Inter-item Correlation (MIC), and Composite Reliability (CR) are calculated, and all demonstrate acceptable value levels, thereby validating the scales used in the study.

To establish the relationship value for $\mathrm{H} 2$, a 5 -point Likert scale ( $1=$ Total Disagreement, to $5=$ Total Agreement) was used to measure relationship value propositions. Analysis performed without theoretical restrictions identified five different product-service strategies, categorizing proposed value propositions into groups from A to $\mathrm{E}$ (table 1). The examination of the scale's internal consistency yields Cronbach alpha values over 0.700 , MIC bellow 0.500 , and CR over 0.700 for all countries, confirming it is a valid instrument for measuring latent variables.

\section{Results}

Confirmatory Factor Analysis (CFA) was used to find the extent to which the indicators selected for the different scales are reliable and valid, and to define relations between the variables. 15 countries were tested, and the reliability of each factor was calculated using composite (CR) and internal (alpha) reliabilities. The content analysis was supported by a review of the literature and through confirmation

Table 1. Items measuring relationship value proposition for product service strategies

\begin{tabular}{|c|c|}
\hline Item Code & Description \\
\hline \multicolumn{2}{|r|}{ Group A } \\
\hline PSA 1 & $\begin{array}{l}\text { Get loyalty points on the album which you can spend to get discounts on other albums or merchandise from the same } \\
\text { artist }\end{array}$ \\
\hline PSA 2 & $\begin{array}{l}\text { Get physical 'trading cards' with the album, buy more and trade with others online to get the complete collection of the } \\
\text { cards }\end{array}$ \\
\hline PSA 3 & $\begin{array}{l}\text { See every possible item (e.g. album, merchandise) you could own for an artist online, register what you own, and share } \\
\text { your collection with others }\end{array}$ \\
\hline PSA 4 & Exclusive access to an online trading site where you can buy and sell rare/limited edition items \\
\hline \multicolumn{2}{|r|}{ Group B } \\
\hline PSB 1 & A music-based console game (e.g. SingStar or Rock Band) \\
\hline PSB 2 & The artist's back catalogue (e.g. older music that has been out for a while) \\
\hline PSB 3 & Another artist's back catalogue (e.g. older music that has been out for a while) from the same record company label \\
\hline \multicolumn{2}{|r|}{ Group C } \\
\hline PSC 1 & $\begin{array}{l}\text { Earn 'points' for helping promote the artist online and get VIP content (e.g. exclusive videos/audio, send questions to } \\
\text { the artist etc.) }\end{array}$ \\
\hline PSC 2 & $\begin{array}{l}\text { Recommend your friends to buy the album (via email or social networks) and receive } 5-10 \% \text { of the price into an online } \\
\text { cash account when they buy it }\end{array}$ \\
\hline PSC 3 & Share that you own the album (with a digital album cover) on a social network site (e.g. Facebook or Twitter) \\
\hline PSC 4 & Meet and chat online with others that have purchased the same album \\
\hline PSC 5 & $\begin{array}{l}\text { Upload your photo online to become part of an artist's album cover made of small photos (e.g. a mosaic). Your photo } \\
\text { along with other fans' photos, is part of an official version of the album cover that you can also print }\end{array}$ \\
\hline PSC 6 & $\begin{array}{l}\text { Give your friends a ' } 24 \text { hour pass' to experience online the extra features that come with the album you have just bought } \\
\text { after which they have the option to buy them }\end{array}$ \\
\hline \multicolumn{2}{|r|}{ Group D } \\
\hline PSD 1 & Get weekly updates from the studio while the album is being recorded (audio/video, photos and other information) \\
\hline PSD 2 & Rate on content and features and provide feedback to the artist \\
\hline \multicolumn{2}{|r|}{ Group E } \\
\hline PSE 1 & Chance to win tickets to see the artist in concert when you purchase their album \\
\hline PSE 2 & The chance to win an exclusive pass to meet the artist \\
\hline
\end{tabular}


with professionals from the music industry, the convergent validity analysis was performed using the average variance extracted (AVE) and individual factor loading. Finally, the discriminant validity analysis establishes that over $50 \%$ of the construct's variance is due to its indicators; the items selected for the different scales have greater factor loadings than the construct in which they are assigned, and the variance between the indicators is greater in relation to their construct than the variance shared between constructs [Byrne, 2006].

A Structural Equation Modelling (SEM) was used, which is appropriate for the specification of the different models whose relationships have been established according to the hypotheses. The goodnessof-fit indices of the models are shown in Table 2 by a range of intervals. The results of the analyses are consistent with the hypotheses proposed above and, therefore, confirm them in some countries (Table 3 , and Figure 2). The percentage of Out of Touch consumers is presented relative to the population and market size of each country.

Table 3 lists the 15 countries analyzed, with current market value and percentage of consumers in the total population identified with an Out of Touch attitude in 2010. The US, Japan, UK, and Germany are the leading countries in terms of size, each representing over $\$ 1$ billion in revenues in 2010. More than 70,000 surveys were conducted and analysis was undertaken to classify consumers by attitude and identify those who are currently categorized as Out of Touch. As mentioned previously, Out of Touch as a proportion of population ranges from $8 \%$ in Sweden to 33\% in the Netherlands, and on average, accounts for $15-20 \%$ of music consumers. The final column of Table 3 shows the propensity to buy for the Out of Touch consumers in each country (Hypothesis 1). Ten out of fifteen countries report a positive propensity, supporting Hypothesis 1; by implying that the group has a positive attitude towards music purchases. The 10 countries present broadly similar parameters, which imply that there is some homogeneity amongst them, and this may initially be taken to suggest a viable global or regional strategy. However, five countries, including the US, Japan, Finland, France and Italy, report a non-positive value and, hence, disconfirm Hypothesis 1. Importantly for this industry, this second group includes two of the biggest markets - the US and Japan - where Out of Touch consumers show little propensity to purchase music and, therefore, could be difficult to recover.

The buying propensity can be divided into different categories: propensity to buy in a product format and propensity to buy in a service format, $\mathrm{Hla}$ and $\mathrm{H} 1 \mathrm{~b}$. To analyse those subcategories of music products, we re-estimate the SEM models for each country using as dependent variables the constructs measuring the willingness to buy music as a product and music as a service. Figure 2 illustrates the combination of the different propensities to buy. In the horizontal axis we report the propensity to buy as a product, $\mathrm{H} 1 \mathrm{a}$, and in the vertical axis we report the propensity to buy as a service, H1b. Finally, the size of the ball represents the general propensity to buy, H1, as illustrated in the last column in Table 3.

In Figure 2, countries under the curve show a preference for music in physical format and countries above the curve seem to prefer online services. Countries nearest the curve (USA, Finland, and France) show equal preference for value offerings and have a low general propensity to buy $(<0.4)$; they offer

\section{Fig. 2. Propensity to buy product and service formats}

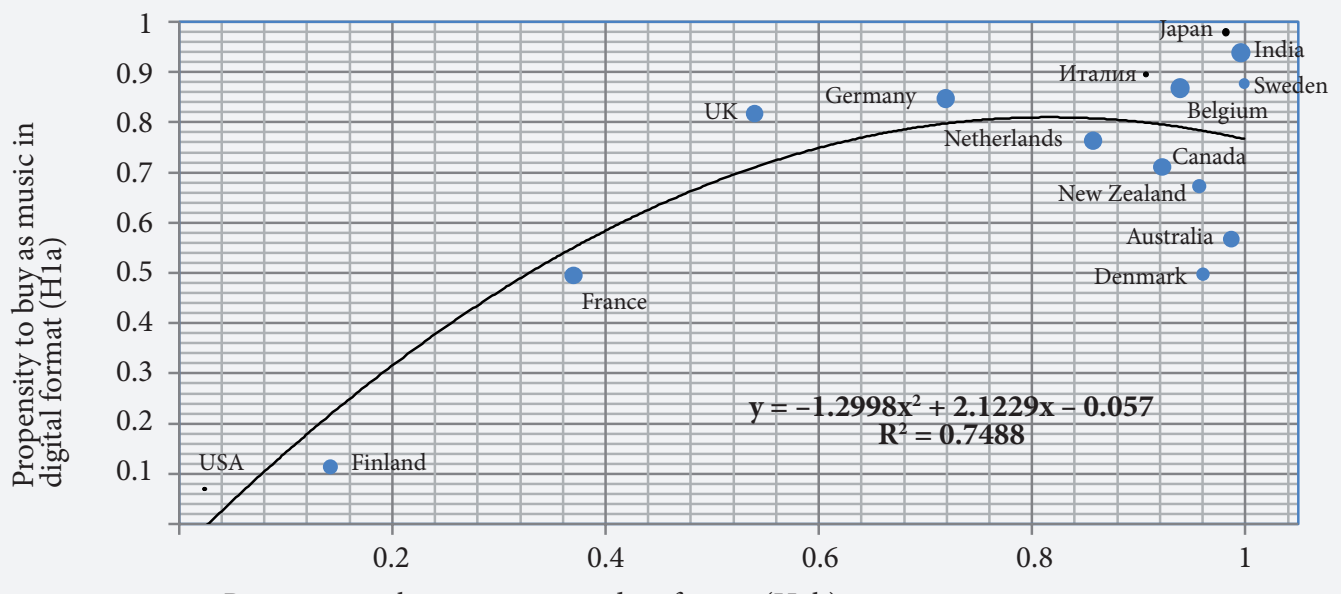

Propensity to buy music in product format $(\mathrm{H} 1 \mathrm{~b})$

Note: The size of the ball determines the propensity to buy music (H1). The parameter takes negative values when it is empty

Source: calculated by the authors. 


\section{Table 2. Indicators of the goodness of fit. Range of values}

\begin{tabular}{|c|l|c|c|c|}
\hline Type of Fit & \multicolumn{1}{|c|}{ Indicator } & Nomenclature & Acceptance Range & Value of Intervals \\
\hline \multirow{5}{*}{ Absolute } & Chi-Square Likelihood & CMIN & Significance test & $\begin{array}{c}\text { All p-vales denote } \\
\text { significance }\end{array}$ \\
\cline { 2 - 5 } & Goodness-of-Fit Index & GFI & $>0.900$ & $(0.932-0.987)$ \\
\cline { 2 - 5 } & Root Mean Square Error & RMSEA & $0.050-0.080$ & $0.058-0.078$ \\
\cline { 2 - 5 } & Root Mean Residual & RMR & $<0.050$ & $(0.038-0.047)$ \\
\hline \multirow{5}{*}{ Incremental } & Compared Fit Index & CFI & $>0.900$ & $(0.946-0.957)$ \\
\cline { 2 - 5 } & Normed Fit Index & NFI & $>0.900$ & $(0.949-0.961)$ \\
\cline { 2 - 5 } & Tucker-Lewis Index & NGFI & $>0.900$ & $(0.944-0.959)$ \\
\cline { 2 - 5 } & Adjusted Goodness Fit & CMINDF & $>0.900$ & $(1.859-3.194)$ \\
\hline Parsimony & Normed Chi-square & & & \\
\hline \multirow{2}{*}{ Source: compiled by the authors. } & & & \\
\hline
\end{tabular}

little hope for additional value for the music industry. Most of the countries that are distant from the curve present high values for the propensity to buy $(>0.6)$. This indicates the general willingness in such countries to engage in marketplace exchanges, although they do not currently engage with combined product and service offerings.

The high correlation between the propensity to buy music as both product and a service $\left(\mathrm{R}^{2}=0.7488\right)$ reflects that consumers across the world value products and services at a similar level. When Out of Touch consumers demonstrate a high (or low) propensity to buy a product, they also show a high (or low) propensity to buy similar service. Thus, a global strategy could be appropriate in our attempts to recover these consumers. However, this group of countries has some heterogeneity: the UK and German consumers are more open to buying music as a service than as a product. In contrast, Out of Touch consumers in Australia, New Zealand, Denmark, the Netherlands and Canada report a greater propensity to buy music in a product format rather than a service. India, Japan, Italy, Sweden and Belgium have strong preference for both formats. This heterogeneity suggests that Asia and Oceania may report some specificity in consumer's preference, where Oceania is product oriented and Asia has a high propensity to buy music in any format.

Regarding the second hypothesis, H2, Figure 3 presents the model relationship used in SEM, and Table 4 compares the value of the parameter $\left(\beta^{*}\right)$ measuring the attitude of Out of Touch consumer groups when they face all of the firm's value offerings (product and service). It also demonstrates the different values

\section{Table 3. Market size characteristics of the sample and propensity to buy}

\begin{tabular}{|l|c|c|c|l|}
\hline \multicolumn{1}{|c|}{ Country } & $\begin{array}{c}\text { Market size 2010, \$US } \\
\text { millions }\end{array}$ & $\begin{array}{c}\text { Number of valid } \\
\text { observations }\end{array}$ & $\begin{array}{c}\text { \% Out of Touch } \\
\text { consumers }\end{array}$ & \multicolumn{1}{|c|}{$\begin{array}{c}\text { Propensity to Buy } \\
\text { (for Out of Touch) }\end{array}$} \\
\hline Canada & 394 & 5478 & 18.22 & H1 (Accepted), $\beta=0.248^{* * *}$ \\
\hline USA & 4167 & 9965 & 10.40 & H1 (Rejected), $\beta=-0.011$ \\
\hline India & 159 & 5173 & 25.05 & H1 (Accepted), $\beta=0.297^{* * *}$ \\
\hline Japan & 3958 & 8185 & 21.79 & H1 (Rejected), $\beta=-0.039$ \\
\hline Australia & 393 & 5340 & 21.33 & H1 (Accepted), $\beta=0.228^{* * *}$ \\
\hline New Zealand & 47 & 2038 & 22.42 & H1 (Accepted), $\beta=0.159^{* * *}$ \\
\hline Belgium & 149 & 256 & 11.72 & H1 (Accepted), $\beta=0.302^{* * *}$ \\
\hline Denmark & 102 & 1545 & 25.50 & H1 (Accepted), $\beta=0.139^{* * *}$ \\
\hline France & 866 & 8387 & 13.29 & H1 (Rejected), $\beta=0.259$ \\
\hline Germany & 1412 & 7564 & 16.70 & H1 (Accepted), $\beta=0.282^{* * *}$ \\
\hline Finland & 70 & 354 & 9.32 & H1 (Rejected), $\beta=0.168$ \\
\hline Italy & 237 & 4593 & 9.98 & H1 (Rejected), $\beta=-0.019$ \\
\hline Netherlands & 261 & 3246 & 33.06 & H1 (Accepted), $\beta=0.273^{* * *}$ \\
\hline Sweden & 136 & 1836 & & H1 (Accepted), $\beta=0.087^{* * *}$ \\
\hline UK & 1378 & 9971 & 12.12 & H1 (Accepted), $\beta=0.244^{* * *}$ \\
\hline *** Significant at the 0.001 level; ${ }^{* *}$ significant at the 0.01 level. & & \\
Source: authors' calculations using data of [IFPI, 2011]. & &
\end{tabular}




\section{Fig. 3. Options to increase Out of Touch consumer attitude to purchasing} through relationship value proposition by region
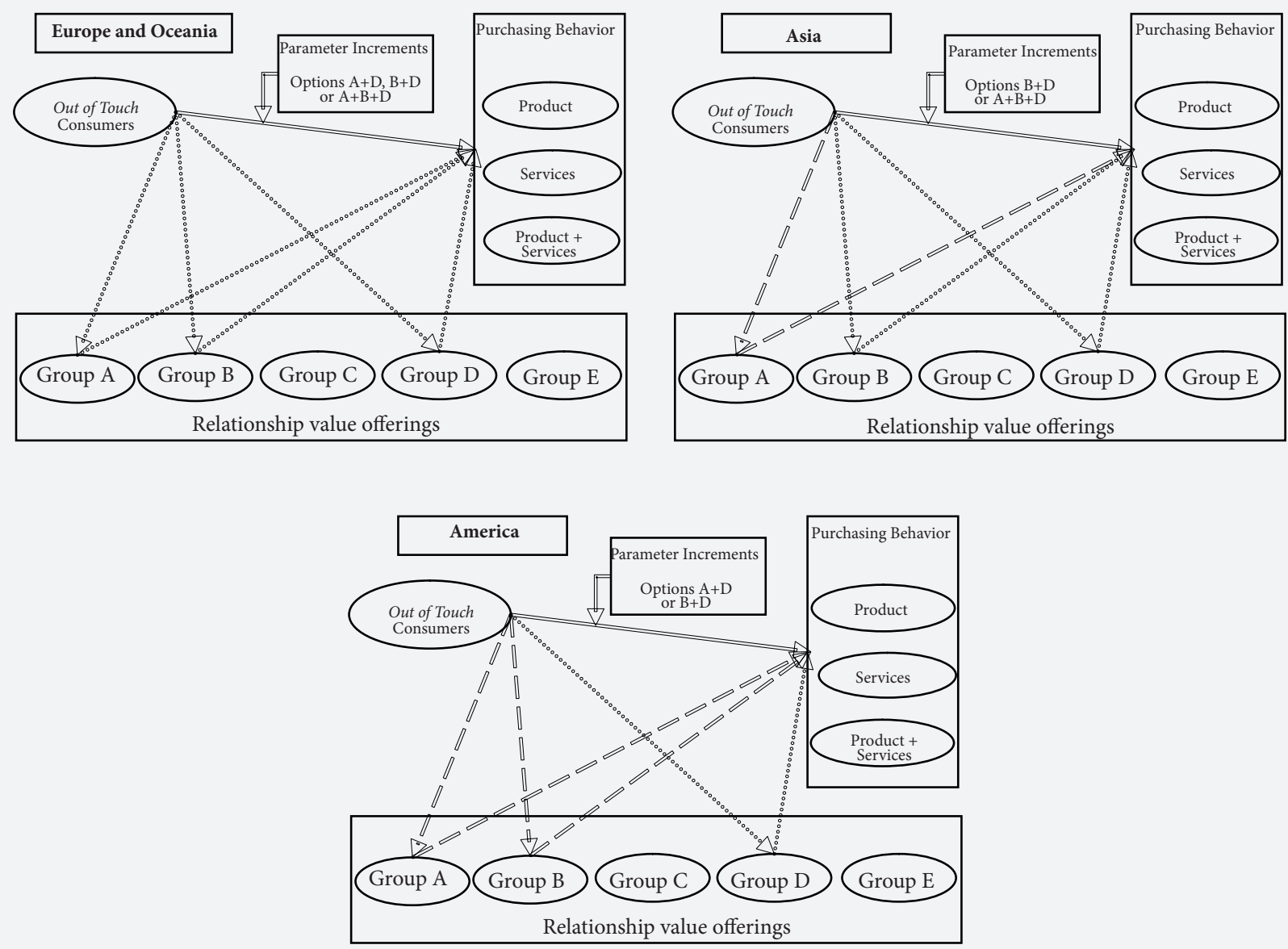

Source: compiled by the authors.

of parameter $\beta$ that measures the same relationship but includes a mixture of value offerings from a standard portfolio [Ngo, O'Cass, 2009]. A number of different value offering were proposed according to industry, which could be employed and combined to form strategies for re-engaging consumers, (value offerings shown in empirically defined groups in table 1). After testing all groups of relationship value propositions from Table 1 (Group $A, B, C, D$ and $E$ ), and combinations of them (i.e. $A+B, A+B+C$, $\mathrm{A}+\mathrm{B}+\mathrm{C}+\mathrm{D}+\mathrm{E} ; \mathrm{B}+\mathrm{C}, \mathrm{B}+\mathrm{C}+\mathrm{D}$ etc.), results obtained show that neither Groups $\mathrm{C}$ nor $\mathrm{E}$ value propositions have any effect on Out of Touch consumers' attitudes. The combination is effective for all countries in Europe and Oceania $(\mathrm{A}+\mathrm{D}$ or $\mathrm{B}+\mathrm{D}$ or $\mathrm{A}+\mathrm{B}+\mathrm{D})$, but is different in America (only $\mathrm{A}+\mathrm{D}$ or $\mathrm{B}+\mathrm{D})$ and Asia (only $\mathrm{B}+\mathrm{D}$ or $\mathrm{A}+\mathrm{B}+\mathrm{D}$ ). This suggests that music MNEs should employ a regional strategy to increase Out of Touch consumer attitudes by using specific combinations of relationship value proposition.

\section{Discussion and conclusions}

The importance of globalization and its impact on competitive dynamics is well documented in the academic literature [Rugman, Oh, 2008]. Research to date has mainly focused on the creation of value propositions by firms [O'Cass, Ngo, 2009], either on their own or jointly with others [Vargo, Lusch, 2004]; they have reported their success drawing on financial data from value exchanges to determine national, regional, or global trends [Contractor et al., 2007]. This study brings in strategic thinking from country and firm level perspectives and builds on recent literature [Vargo, Lusch, 2008] on the role of the consumer and potential consumer as a resource for the company and an active participant in value creation. A strategy targeted at a global, regional, or national level needs consumers attitudes 


\section{Table 4. Relationship value propositions (Product-Service strategies)}

\begin{tabular}{|c|c|c|}
\hline Country & Attitude to all propositions & Attitude to combinations of value proposition \\
\hline \multirow{3}{*}{ Canada } & \multirow{3}{*}{$\beta^{\star}=0.248^{* * *}$} & $\mathbf{A}+\mathbf{D} \quad \beta=0.782^{* \star *}$ \\
\hline & & $\mathbf{B}+\mathbf{D} \quad \beta=0.805^{* * *}$ \\
\hline & & $(A+B+D \quad \beta=0.139)$ \\
\hline \multirow{3}{*}{ USA } & \multirow{3}{*}{$\beta^{*}=-0.011$} & $\mathbf{A}+\mathbf{D} \beta=0.571^{* * *}$ \\
\hline & & $\mathbf{B}+\mathbf{D} \beta=0.608^{* *}$ \\
\hline & & $(\mathrm{A}+\mathrm{B}+\mathrm{D} \quad \beta=-0.563)$ \\
\hline \multirow{3}{*}{ India } & \multirow{3}{*}{$\beta^{*}=0.297^{* * *}$} & $(A+D \quad \beta=-0.268)$ \\
\hline & & $\mathbf{B}+\mathbf{D} \beta=0.802^{* * *}$ \\
\hline & & $\mathbf{A}+\mathbf{B}+\mathbf{D} \beta=0.876^{* *}$ \\
\hline \multirow{3}{*}{ Japan } & \multirow{3}{*}{$\beta^{*}=-0.039$} & $(A+D \beta=-0.634)$ \\
\hline & & $\mathbf{B}+\mathbf{D} \beta=0.601^{\star * *}$ \\
\hline & & $\mathbf{A}+\mathbf{B}+\mathbf{D} \beta=0.842^{* * *}$ \\
\hline \multirow{3}{*}{ Australia } & \multirow{3}{*}{$\beta^{*}=0.228^{* * *}$} & $\mathrm{~A}+\mathrm{D} \beta=0.479^{* * *}$ \\
\hline & & $\mathbf{B}+\mathbf{D} \beta=0.402^{* * *}$ \\
\hline & & $\mathbf{A}+\mathbf{B}+\mathbf{D} \beta=0.477^{* * *}$ \\
\hline \multirow{3}{*}{ New Zealand } & \multirow{3}{*}{$\beta^{*}=0.159^{* * *}$} & $\mathbf{A}+\mathbf{D} \beta=0.421^{* * *}$ \\
\hline & & $\mathbf{B}+\mathbf{D} \beta=0.405^{\star * *}$ \\
\hline & & $\mathbf{A}+\mathbf{B}+\mathbf{D} \beta=0.469^{* * *}$ \\
\hline \multirow{3}{*}{ Belgium } & \multirow{3}{*}{$\beta^{*}=0.302^{\star * *}$} & $\mathrm{~A}+\mathrm{D} \beta=0.643^{\star * \star}$ \\
\hline & & $\mathrm{B}+\mathrm{D} \beta=0.658^{* * *}$ \\
\hline & & $A+B+D \beta=0.597^{* *}$ \\
\hline \multirow{3}{*}{ Denmark } & \multirow{3}{*}{$\beta^{*}=0.139^{* * *}$} & $\mathbf{A}+\mathbf{D} \beta=0.452^{* * *}$ \\
\hline & & $\mathrm{B}+\mathrm{D} \beta=0.465^{\star * *}$ \\
\hline & & $\mathbf{A}+\mathbf{B}+\mathbf{D} \beta=0.499^{* * *}$ \\
\hline \multirow{3}{*}{ Finland } & \multirow{3}{*}{$\beta^{*}=0.168^{* * *}$} & $\mathrm{~A}+\mathrm{D} \beta=0.467^{* * *}$ \\
\hline & & $\mathbf{B}+\mathbf{D} \beta=0.471^{* * *}$ \\
\hline & & $\mathrm{A}+\mathrm{B}+\mathrm{D} \beta=0.485^{* * *}$ \\
\hline \multirow{3}{*}{ France } & \multirow{3}{*}{$\beta^{*}=0.259$} & $\mathrm{~A}+\mathrm{D} \beta=0.559^{\star \star \star}$ \\
\hline & & $\mathbf{B}+\mathbf{D} \beta=0.471^{\star * *}$ \\
\hline & & $\mathbf{A}+\mathbf{B}+\mathbf{D} \beta=0.517^{* * *}$ \\
\hline \multirow{3}{*}{ Germany } & \multirow{3}{*}{$\beta^{*}=0.282^{\star * *}$} & $\mathbf{A}+\mathbf{D} \beta=0.519^{* *}$ \\
\hline & & $\mathbf{B}+\mathbf{D} \beta=0.512^{* * *}$ \\
\hline & & $\mathbf{A}+\mathbf{B}+\mathbf{D} \beta=0.705^{\star * *}$ \\
\hline \multirow{3}{*}{ Italy } & \multirow{3}{*}{$\beta^{*}=-0.319$} & $\mathrm{~A}+\mathrm{D} \beta=0.450^{* * *}$ \\
\hline & & $\mathbf{B}+\mathbf{D} \beta=0.648^{\star * *}$ \\
\hline & & $\mathbf{A}+\mathbf{B}+\mathbf{D} \beta=0.674^{* *}$ \\
\hline \multirow{3}{*}{ Netherlands } & & $\mathbf{A}+\mathbf{D} \beta=0.439^{* * *}$ \\
\hline & $\beta^{\star}=0.273^{* * *}$ & $\mathbf{B}+\mathbf{D} \beta=0.473^{\star * \star}$ \\
\hline & & $\mathbf{A}+\mathbf{B}+\mathbf{D} \beta=0.392^{* * *}$ \\
\hline & & $\mathbf{A}+\mathbf{D} \beta=0.361^{* * *}$ \\
\hline Sweden & $\beta^{\star}=0.087^{\star * \star}$ & $\mathbf{B}+\mathbf{D} \beta=0.410^{* * *}$ \\
\hline & & $\mathrm{A}+\mathrm{B}+\mathrm{D} \beta=0.444^{* * *}$ \\
\hline & & $\mathbf{A}+\mathbf{D} \beta=0.768^{\star * \star}$ \\
\hline UK & $\beta^{\star}=0.185^{\star * \star}$ & $\mathbf{B}+\mathbf{D} \beta=0.606^{* * *}$ \\
\hline & & $\mathbf{A}+\mathbf{B}+\mathbf{D} \beta=0.821^{* *}$ \\
\hline
\end{tabular}


to be homogenous at the same level of analysis, since strategies have to be inflexible if the firm is to obtain competitive advantage. Accordingly, this study contributes to this field by exploring the attitude of consumers who are positively disposed to a value offering, yet currently have limited engagement and are a source of potentially unrealized revenue. These consumers do not appear in corporate reported data and yet form a potentially significant source of future income. An investigation into the attitude to offerings facilitates an understanding of consumers' perception of value offering, and provides an exogenous perspective on how strategy can be crafted to create or maintain value for consumers [O'Cass, $\mathrm{Ngo}, 2011]$ at an appropriate level of analysis. This level could be global [Yip, 2003], regional [Rugman, Oh, 2008; Rugman, Verbeke, 2003], national, or distinct yet interrelated [Ghemawat, 2005]. The conclusions agree with DeSarbo et al. [DeSarbo et al., 2001] and provide empirical evidence of the importance of consumer value analysis when firms deal with heterogeneous markets.

This paper also contributes to the understanding that product and services need to be managed in different ways [Bustinza et al., 2013a]. Services are more amenable to global upstream delivery, whereas product format relies upon national or regional assets [Graham et al., 2004]. Findings revealed some regional level of preference that may be influenced by national or regional specific factors [Dunning et al., 2007]. However, in the case of consumer attitudes to a different product or service, it is found that the selection of the value offering provided becomes the critical determinant of the value creation process [Breunig et al., 2013; Parry et al., 2012]. The study also explores the potential of bundling product, service, and relationship value propositions [O'Cass, Ngo, 2011; Vargo, Lusch, 2004]. The findings indicate that specific bundles of related products and services re-engaged Out of Touch consumers at the regional level of analysis. Empirical analysis shows that contrary to the optimal strategies based on national subsidiaries during the second half of the $20^{\text {th }}$ century [Bakker, 2006], regional strategies are preferable in creating value and regional teams within firms. Further, these are important when developing knowledge as they facilitate understanding of the heterogeneity of regions, as described by Ritzer [Ritzer, 2003]. While a strategy to provide value offerings globally may be appropriate in the digital domain [Yip, 2003], the value bundles offered to consumers are more effective if they are made to match regional consumer market requirements; this would provide an important strategic contribution. A global delivery system offering a portfolio of product and service may then be configured to regionally bundle offers that are appropriate to the identified consumer value propositions.

\section{Managerial relevance}

The analysis of consumers explores the extent to which homogeneity exists in their attitudes towards a product/service offer and if it does, at what level: global, regional, or national. Where such homogeneity exists, strategies should support the provision of value offer at the appropriate level. The analysis here has found a large group of consumers with the resources to buy but who did not make any purchases. This group is termed Out of Touch, and their behaviour was explored across 15 countries.

We focused on the group's attitudes to purchasing different value offerings and then analysed national markets in an effort to identify the appropriate level of commonality [Dunning et al., 2007]. The analysis shows that homogeneity exists in consumer attitudes across many countries and the Out of Touch consumers can be re-engaged following the analysis and identification of appropriate offers, which facilitate the transfer of standard strategy and practice across national borders [Katsikeas et al., 2006]. However, statistical analysis showed that in four important markets (US, Japan, France, and Italy), potentially valuable consumers did not have a high propensity to buy. This is both a concern and an opportunity for managers in the music industry. Our analysis indicates that a global strategy that seeks to engage the Out of Touch grouping will potentially succeed in many markets, but it would not succeed in two of the global largest markets, the United States and Japan, and the two key European markets of Italy and France. Overall, these markets account for approximately 60\% of industry revenues. This is interesting as it demonstrates that care must be taken when assessing strategy, particularly when strategies are being transferred between countries. What works in a number of smaller markets may not work in larger ones and vice versa. Future work could seek to understand why this is the case. Repetition of the analysis undertaken, where data are available may help reveal whether strategies employed successfully are appropriate and transferrable, or why failures occurred. The study also concludes that the music industry is not global but rather regionally based, suggesting that large firms should employ regional managers or teams.

\section{Future lines of research and limitations}

Going forward, as we gain larger and more detailed data, we will be able to identify accurately people from around the world who have specific attitudes towards products or services. With this level of granularity and using digital media strategies, it may be possible to utilize global strategies to target consumers segmented by attitude rather than geography. Further, we may be able to understand why strategy may or may not be transferrable between nations.

The data used in this paper are unique and rich but face some limitations that affect to what extent we can generalize from the results. The timeframe of this research is limited to early 2011, and hence we do not 
capture changes in attitudes over time. A longitudinal study may help provide a greater understanding of preference evolution in markets. The purchase propensity is based on survey responses (attitudes) rather than actual data on consumer behaviour. Whilst we are confident that significant differences in the estimated propensity parameters relate to different value perceptions, we do not observe actual purchase behaviour where there is a monetary exchange. We have assumed that the different music formats are of equal quality around the world and have not taken on board national differences, competition, and piracy that may influence attitudes.

\section{References}

Afuah A. (2002) Mapping technological capabilities into product markets and competitive advantage: The case of cholesterol drugs. Strategic Management Journal, vol. 23, no 2, pp. 171-179.

Bakker G. (2006) The making of a music multinational: PolyGram's international businesses, 1945-1998. The Business History Review, vol. 80, no 1, pp. 81-123.

Ballard D.J., Ogola G., Fleming N.S., Heck D., Gunderson J., Mehta R., Khetan R., Kerr J.D. (2009) The Impact of Standardized Order Sets on Quality and Financial Outcomes. Patient Safety: New Directions and Alternative Approaches (Vol. 2: Culture and Redesign) (eds. K. Henriksen, J.B. Battles, M.A. Keyes), Rockville, MD: U.S. Agency for Healthcare Research and Quality.

Berthon P., Pitt L., McCarthy I., Kates S. (2007) When customers get clever: Managerial approaches to dealing with creative consumers. Business Horizons, vol. 50, no 1, pp. 39-47.

Boisot M. (1998) Knowledge assets: Securing competitive advantage in the information economy. New York: Oxford University Press.

Boone C., Van Witteloostuijn A., Carroll G.R. (2002) Resource distributions and market partitioning: Dutch daily newspapers, 1968 to 1994. American Sociological Review, vol. 67, no 3, pp. 408-431.

Breunig K.J., Kvålshaugen R., Hydle K.M. (2014) Knowing your boundaries: Integration opportunities in international professional service firms. Journal of World Business, vol. 49, no 4, pp. 502-511. DOI: 10.1016/j.jwb.2013.12.004.

Briscoe D.R., Schuler R.S., Claus L. (2009) International Human Resource Management: Policies and practices for multinational enterprises (Global HRM) (3rd ed.), New York: Routledge.

Brynjolfsson E., Hu Y., Smith M.D. (2006) From niches to riches: Anatomy of the long tail. Sloan Management Review, vol. 47, no 4, pp. 67-71.

Bustinza O.F., Parry G.C., Vendrell-Herrero F. (2013a) Supply and demand chain management: The effect of adding services to product offerings. Supply Chain Management: An International Journal, vol.18, no 6, pp. 618-629.

Bustinza O.F., Vendrell-Herrero F., Parry G.C., Myrthianos V. (2013b) Music Business Models and Piracy. Industrial Management \& Data Systems, vol. 113, no 1, pp. 4-22.

Byrne B.M. (2006) Structural equation modeling with EQS: Basic concepts, applications, and programming, New York: Psychology Press.

Chandra Y., Coviello N. (2010) Broadening the concept of international entrepreneurship: 'Consumers as International Entrepreneurs'. Journal of World Business, vol. 45, no 3, pp. 228-236.

Contractor F.J., Kumar V., Kundu S.K. (2007) Nature of the relationship between international expansion and performance: The case of emerging market firms. Journal of World Business, vol. 42, no 4, pp. 401-417.

De Jong G., Phan T.B., Van Ees H. (2011) Does the meta-environment determine firm performance? Theory and evidence from European multinational enterprises. International Business Review, vol. 20, no 4, pp. 454-465.

Dellestrand H. (2011) Subsidiary embeddedness as a determinant of divisional headquarters involvement in innovation transfer processes. Journal of International Management, vol. 17, no 3, pp. 229-242.

DeSarbo W.S., Jedidi K., Sinha I. (2001) Customer value analysis in a heterogeneous market. Strategic Management Journal, vol. 22, no 9, pp. 845-857.

Djelic M.L., Quack S. (2003) Globalization and institutions: Redefining the rules of the economic game, Cheltenham: Edward Elgar.

Dunning J.H., Fujita M., Yakova N. (2007) Some macro-data on the regionalization/globalization debate: A comment on the Rugman/Verbeke analysis. Journal of International Business Studies, vol. 38, pp. 177-199.

Ellis P.D. (2006) Market orientation and performance: A meta-analysis and cross-national comparisons. Journal of Management Studies, vol. 43, no 5, pp. 1089-1107.

Evans J., Mavondo F.T., Bridson K. (2008) Psychic distance: Antecedents, retail strategy implications, and performance outcomes. Journal of International Marketing, vol. 16, no 2, pp. 32-63.

Feld S. (2001) A sweet lullaby for world music. Globalization, vol. 12, no 1, pp. 189-216.

Ferreira F., Waldfogel J. (2010) Pop internationalism: Has a half century of World music trade displaced local culture? (NBER Working Paper 15964), Cambridge, MA: National Bureau of Economic Research.

Ghemawat P. (2005) Regional strategies for global leadership. Harvard Business Review, vol. 83, no 12, pp. 98-108.

Ghoshal S., Westney D.E. (1993) Organization theory and the multinational corporations, New York: St Martin's Press.

Giddens A. (2011) Runaway world: How globalization is reshaping our lives, London: Profile Books.

Graham G., Burnes B., Lewis G.J., Langer J. (2004) The transformation of the music industry supply chain: A major label perspective. International Journal of Operations \& Production Management, vol. 24, no 11, pp. 1087-1103.

Hair J.F., Anderson R.E., Tatham R.L., Black W. (2001) Multivariate data analysis, London: Prentice Hall Pearson Education. 
Hargrave T.J., van de Ven A.H. (2009) Institutional work as the creative embrace of contradiction. Institutional work: Actors and agency in institutional studies of organizations (eds. T.B. Lawrence, R. Suddaby, B. Leca), New York: Cambridge University Press, pp. 120-140.

Hitt M. A., Hoskisson R.E., Ireland R.D. (1994) A mid-range theory of the interactive effects of international and product diversification on innovation and performance. Journal of Management, vol. 20, no 2, pp. 297-326.

Ho W.C. (2003) Between globalisation and localisation: A study of Hong Kong popular music. Popular Music, vol. 22, no 2, pp. 143-157.

Hultman M., Robson M.J., Katsikeas C.S. (2009) Export product strategy fit and performance: An empirical investigation. Journal of International Marketing, vol. 17, no 4, pp. 1-23.

Husted B.W., Allen D.B. (2006) Corporate social responsibility in the multinational enterprise: Strategic and institutional approaches. Journal of International Business Studies, vol. 37, no 6, pp. 838-849.

IFPI (2011) IFPI digital music report 2011: Music at the touch of a button. London: IFPI. Available at: www.ifpi.org/ content/library/DMR2011.pdf, accessed 24.06.2015.

Johanson J., Vahlne J.E. (1977) The internationalization process of the firm: A model of knowledge development and increasing foreign market commitments. Journal of International Business Studies, vol. 8, no 1, pp. 23-32.

Kafouros M.I., Buckley P.J., Sharp J.A., Wang C. (2008) The role of internationalization in explaining innovation performance. Technovation, vol. 28, no 1-2, pp. 63-74.

Katsikeas C.S., Samiee S., Theodosiou M. (2006) Strategy fit and performance consequences of international marketing standardization. Strategic Management Journal, vol. 27, no 9, pp. 867-890.

Kirca A.H., Jayachandran S., Bearden W.O. (2005) Market orientation: A meta-analytic review and assessment of its antecedents and impact on performance. Journal of Marketing, vol. 69, no 2, pp. 24-41.

Kogut B., Singh H. (1988) The effect of national culture on the choice of entry mode. Journal of International Business Studies, vol. 19, no 3, pp. 411-432.

Kucuk U.S., Krishnamurthy S. (2007) An analysis of consumer power on the Internet. Technovation, vol. 27, no 1-2, pp. 47-56.

Lepak D., Smith K.G., Taylor M.S. (2007) Value creation and value capture: A multilevel perspective. Academy of Management Review, vol. 32, no 1, pp. 180-194.

Lusch R.F., Vargo S.L., Tanniru M. (2010) Service, value networks and learning. Journal of the Academy of Marketing Science, vol. 38, no 1, pp. 19-31.

Madhok A. (1997) Cost, value and foreign market entry mode: The transaction and the firm. Strategic Management Journal, vol. 18, no 1, pp. 39-61.

Morgan N.A., Vorhies D.W., Mason C.H. (2009) Market orientation, marketing capabilities, and firm performance. Strategic Management Journal, vol. 30, no 8, pp. 909-920.

Negus K. (1999) Music genres and corporate cultures, London: Psychology Press.

Neu W.A., Brown S. (2005) Forming successful business-to-business services in goods-dominant firms. Journal of Service Research, vol. 8, no 1, pp. 3-17.

Ngo L.V., O’Cass A. (2009) Creating value offerings via operant resource-based capabilities. Industrial Marketing Management, vol. 38, no 1, pp. 45-59.

O'Cass A., Ngo L.V. (2011) Examining the firm's value creation process: A managerial perspective of the firm's value offering strategy and performance. British Journal of Management, vol. 22, no 4, pp. 646-671.

Ordanini A., Pasini P. (2008) Service co-production and value co-creation: The case for a service-oriented architecture (SOA). European Management Journal, vol. 26, no 5, pp. 289-297.

O'Regan N. (2012) Entrepreneurship and innovation: Overview. Strategic Change, vol. 21, no 5-6, pp. 193-198. DOI: $10.1002 /$ jsc.1903Ltd.

Parry G., Bustinza O.F., Vendrell-Herrero F. (2012) Servitisation and value co-production in the UK music industry: An empirical study of consumer attitudes. International Journal of Production Economics, vol. 135, no 1, pp. 320-332.

Payne A., Holt S. (2001) Diagnosing customer value: Integrating the value process and relationship marketing. British Journal of Management, vol. 12, no 7, pp. 159-182.

Pieterse J.N. (2009) Globalization and culture: Global mélange, London: Rowman \& Littlefield Publishers.

Prahalad C.K., Ramaswamy V. (2000) Co-opting customer competence. Harvard Business Review, vol. 78, no 1, pp. $79-87$.

Ritzer G. (2003) Rethinking globalization: Glocalization/grobalization and something/nothing. Sociological Theory, vol. 21, no 3, pp. 193-209.

Robertson R., Khondker H.H. (1998) Discourses of globalization. International Sociology, vol. 13, no 1, pp. 25-40.

Rugman A.M. (2009) Theoretical aspects of MNEs from emerging markets. Emerging multinationals in emerging markets (eds. R. Ramamurti, J.V. Singh), Cambridge: Cambridge University Press, pp. 42-63.

Rugman A.M., Oh C.H. (2008) Korea's multinationals in a regional world. Journal of World Business, vol. 43, no 1, pp. 5-15.

Rugman A.M., Verbeke A. (2003) Regional multinationals and triad strategy. Leadership in international business education and research (Series: Research in global strategic management, vol. 8) (ed. A.M. Rugman), London: Emerald Group Publishing, pp. 253-268.

Schmid S., Kotulla T. (2011) 50 years of research on international standardization and adaptation: From a systematic literature analysis to a theoretical framework. International Business Review, vol. 20, no 5, pp. 491-507.

Singer M., Donoso P. (2008) Upstream or downstream in the value chain? Journal of Business Research, vol. 61, no 6, pp. 669-677.

Sirmon D.G., Hitt M.A., Ireland R.D. (2007) Managing firm resources in dynamic environments to create value: Looking inside the black box. Academy of Management Review, vol. 32, no 1, pp. 273-292. 
Srivastava R.K., Fahey L., Christensen H.K. (2001) The resource-based view and marketing: The role of market-based assets in gaining competitive advantage. Journal of Management, vol. 27, no 6, pp. 777-802.

Stokes M. (2004) Music and the global order. Annual Review of Anthropology, vol. 33, pp. 47-72.

Swatman P.M.C., Krueger C., Van Der Beek K. (2006) The changing digital content landscape: An evaluation of e-business model development in European online news and music. Internet Research, vol. 16, no 1, pp. 53-80.

Vandermerwe S., Rada J. (1988) Servitization of Business: Adding Value by Adding Services. European Management Journal, vol. 6, pp. 314-324. Available at: http://dx.doi.org/10.1016/0263-2373(88)90033-3, accessed 14.08.2015.

Vargo S.L., Lusch R.F. (2004) Evolving to a new dominant logic for marketing. Journal of Marketing, vol. 68, no 1, pp. 1-17.

Vargo S.L., Lusch R.F. (2008) From goods to service(s): Divergences and convergences of logics. Industrial Marketing Management, vol. 37, no 3, pp. 254-259.

Wise R., Baumgartner P. (1999) Go downstream. Harvard Business Review, vol. 77, no 5, pp. 133-141.

Yip G. (2003) Total global strategy II, Prentice Hall, Upper Saddle River, NJ: Pearson Education International. 